\title{
Cutis marmorata marbling in an individual with decompression illness following repetitive SCUBA diving
}

\author{
Michael M Modell
}

Brighton and Sussex Medical School, UK

Correspondence to

Michael Modell,

m.modell1@uni.bsms.ac.uk

Accepted 20 May 2014
CrossMark

\footnotetext{
To cite: Modell MM. BMJ Case Rep Published online: [please include Day Month Yearl doi:10.1136/bcr-2014203975
}

\section{DESCRIPTION}

A 49-year-old female self-contained underwater breathing apparatus (SCUBA) diver who presented to the Hyperbaric Medical Center with sudden skin discolouration, fatigue, dizziness and blurred vision $3 \mathrm{~h}$ following a dive. All dives, made on air, were up to $25 \mathrm{~m}$ deep, with no omission of decompression safety stops.

Decompression illness (DCI) is a result of nitrogen accumulation within the body's tissues, causing reduced blood flow and impaired oxygen delivery. DCI can affect multiple systems, for example, central nervous system, musculoskeletal, cardiovascular and skin. ${ }^{1}$ Cutis marmorata, a cutaneous manifestation of DCI is indicative of systemic DCI pathology. ${ }^{2}$ Early diagnosis and investigations are essential. The rash begins with cyanotic mottling and may quickly spread peripherally, becoming erythematous (figure 1). Marbling indicates nitrogen bubbles present within tissues and blood vessels, ${ }^{1}$ and is due to vascular congestion and an inflammatory response towards the bubbles. ${ }^{3}$

The patient was diagnosed with DCI with skin, lymphatic and neurological involvement. There were neurological signs of nystagmus, decreased

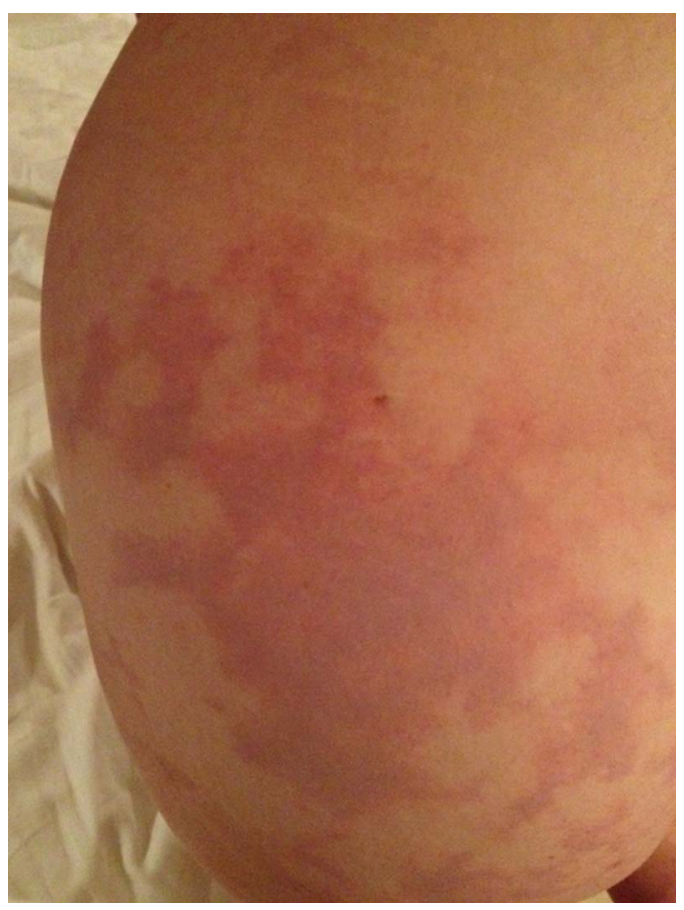

Figure 1 Cutis marmorata marbling (left gluteal) occurring in a 49-year-old female self-SCUBA diver with decompression illness. upper and lower limb strength and lymphoedema. Non-specific symptoms such as fatigue, lethargy, malaise, headache, generalised aches and pains are most commonly reported. ${ }^{1}$

She underwent recompression inside a hyperbaric chamber for three consecutive days and was recommended daily hydrotherapy exercises. The rash resolved on recompression and a full neurological recovery was made with no clinical deficits detectable. A likely cause for her DCI could be repetitive and multiple day diving, leading to an accumulation of residual nitrogen within tissues.

Follow-up investigations revealed a patent foramen ovale, which may have allowed bubbles to bypass the pulmonary filtration system, contributing to her DCI. ${ }^{1}$

\section{Learning points}

- Decompression illness is a serious complication requiring oxygen and urgent hyperbaric recompression treatment.

- Any individual with positive responses to the diving medical questionnaire should be referred to a local diving medical specialist.

- The UK Sport Diving Medical Committee, Diver's Alert Network (DAN) and the Diving Diseases Research Centre (DDRC) are good sources of medical information for diving.

Acknowledgements The author would like to acknowledge Dr Adel Taher, Hyperbaric Medical Center, Sharm el Sheikh, Egypt; Dr Ahmed Sakr, MD Hyperbaric Medical Center, Sharm el Sheikh, Egypt.

Competing interests None.

Patient consent Obtained.

Provenance and peer review Not commissioned; externally peer reviewed.

\section{REFERENCES}

1 Walker R. Decompression sickness: history and physiology. In: Edmonds C, Lowry C, Pennefather J, Walker R. eds. Diving and subaquatic medicine. 4th edn. London: Edward Arnold Ltd 2005:112-50.

2 Kalentzos VN. Images in clinical medicine. Cutis marmorata in decompression sickness. N Engl J Med 2010;362:e67

3 Oode $Y$, Yanagawa $Y$, Inoue $T$, et al. Cutaneous manifestation of decompression sickness: cutis marmorata. Intern Med 2013;52:2479. 


\section{Images in...}

Copyright 2014 BMJ Publishing Group. All rights reserved. For permission to reuse any of this content visit http://group.bmj.com/group/rights-licensing/permissions.

BMJ Case Report Fellows may re-use this article for personal use and teaching without any further permission.

Become a Fellow of BMJ Case Reports today and you can:

- Submit as many cases as you like

- Enjoy fast sympathetic peer review and rapid publication of accepted articles

- Access all the published articles

- Re-use any of the published material for personal use and teaching without further permission

For information on Institutional Fellowships contact consortiasales@bmjgroup.com

Visit casereports.bmj.com for more articles like this and to become a Fellow 